\title{
Neo-monastics in North Carolina, de-growth and a theology of enough
}

\author{
Amy Cox Hall ${ }^{1}$ \\ Amherst College, USA
}

\begin{abstract}
This article examines one intentional Christian community's attempts to live a life that eschews consumerism and material growth for a life focused on spiritual growth and collectivity. I articulate intentional Christian living, often referred to as neo-monasticism, with the de-growth movement. I do so to offer insight into the practice and pragmatics of de-growth's broadly understood call to revalue the ideals of life in an effort to reduce consumption. Neo-monasticism and de-growth have much in common including the critique of consumerism, individualism and increasing inequality. Both also promote relationships, locality, sharing, slowing down and quality of life over efficiency and incessant work. Drawing on four years of research with one residential Christian community, I suggest that the most challenging aspect of sharing a life together and slowing down is not simply consuming less or pooling resources but rethinking and living social values not driven by a consumerist-growth paradigm. While some de-growth advocates, such as Serge Latouche, promote ideals of harmony and oneness, in practice, living simply and sharing a life together is challenging and conflictual, even when religiously inspired.
\end{abstract}

Key Words: De-growth, neo-monasticism, emerging church, millennial generation, Christianity, sharing economy

\section{Résumé}

Cet article analyse une tentative d'une communauté chrétienne intentionnelle de vivre une vie qui rejette la consommation et la croissance matérielle, et qui préfère une vie concentrée sur la croissance spirituelle et la vie communautaire. Je précise que la vie chrétienne intentionnelle, souvent désignée " néo-monachisme ", est liée au mouvement de décroissance. J'associe ces deux pour offrir une connaissance de la pratique et de la pragmatique au sens large de l'appel du mouvement de décroissance pour réévaluer nos idéaux de vie dans un effort de réduire la consommation. Le néo-monachisme et la décroissance ont beaucoup en commun, y compris la critique de la consommation, de l'individualisme et de l'accroissement des inégalités. Ces deux promeuvent les relations, la localité, le partage, le ralentissement, et la qualité de la vie au-dessus de l'efficacité et le travail incessant. En tirant des données acquises pendant quatre années de recherche dans une communauté chrétienne résidentielle, j'insinue que le défi le plus difficile de partager une vie communautaire et inciter le ralentissement ne s'agit pas de simplement consommer moins ou de mettre en commun des ressources, mais de réviser et vivre avec des valeurs sociales qui ne sont pas entraînées par un paradigme consumériste croissant. Alors que certains partisans de la décroissance, tels que Serge Latouche, promeuvent des idéaux d'harmonie et d'unité, en pratique, vivre dans la simplicité et dans le partage d'une vie commune devient difficile et conflictuelle, même si elle est inspirée par la religion.

Mots-clés: Décroissance, néo-monachisme, église émergente, génération du millénaire, le christianisme, économie de partage

\footnotetext{
${ }^{1}$ Dr. Amy Cox Hall, Visiting Assistant Professor at Amherst College, Department of Anthropology and Sociology, Morgan Hall, Amherst, MA. Email: acoxhall "at" amherst.edu. The author wishes to thank all of the residents of the intentional community and its affiliated church for sharing their experiences with me. Thank you also to Susan Paulson, Lisa Gezon, Casey Walsh and Bill Girard for their comments on earlier drafts. This is the seventh article in Lisa L. Gezon and Susan Paulson (eds.) 2017. "Degrowth, culture and power", Special Section of the Journal of Political Ecology, 24: 425-466.
} 


\section{Resumen}

Este artículo examina el empeño de una comunidad cristiana para vivir una vida que evita el consumismo y el incremento de bienes materiales para así enfocarse en el crecimiento espiritual y la colectividad. Encuentro conexiones entre esta vida cristiana intencional, a menudo llamada neo-monasticismo, con el movimiento del decrecimiento. Lo hago para ofrecer una percepción del aspecto pragmático del llamado a revaluar los ideales de la vida en un esfuerzo a reducir la cantidad de recursos consumidos. El neo-monasticismo y el decrecimiento tienen mucho en común, incluyendo la crítica al consumismo, al individualismo y al aumento de la desigualdad. Ambos promueven las relaciones humanas, la localidad, el compartir, reducir la velocidad y darle preferencia a la cualidad de vida sobre la eficiencia y el trabajo incesante. Basándome en cuatro años de investigación con una comunidad cristiana residencial, sugiero que el aspecto más difícil de compartir la vida y de reducir la velocidad de ella no es simplemente el consumir menos, ni el manejo comunal de recursos, sino el sentir y vivir los valores sociales que no se rigen por la paradigma del crecimiento consumista. Mientras que algunos defensores del decrecimiento, como Serge Latouche, promueven ideales de la harmonía y la unidad, en la practica, el vivir sencillamente y compartir la vida es difícil y conflictivo, hasta cuando es inspirado por la religiosidad.

Palabras clave: decrecimiento, neo-monasticismo, la iglesia emergente, los Millennials, cristianismo, economía communal

\section{Introduction}

Over the course of the last decade, the idea of living in intentional or neo-monastic communities has increasingly attracted younger Christian adults. Communities offer a rule of life that orders the day through collective prayer, meals and sometimes work. Although there are various iterations of what daily life looks like, emphasis is placed on modeling one's own life on the life of Jesus. Intentional communities take a wide variety of forms, such as eco-housing, student co-ops and hospitality houses, with some participants looking to experience community life as a temporary experiment and others as a lifelong commitment. In either case, residents typically share the sensibility of wanting to live life outside of the societal norm and for a common purpose. Key components to neo-monasticism are its emphasis on social justice and cooperation. ${ }^{2}$

In 2006, Shane Claiborne wrote The irresistible revolution: living as an ordinary radical. The book, which was based on his experience as a Christian college student who helped start The Simple Way, a hospitality house in Philadelphia, heralded a new economy that focused on a "theology of enough." The bestseller became a manifesto for a new generation of Christians, urging its readers to fight everything from corporate greed, to consumerism, to war. The book and The Simple Way became a beacon for many young Christians who were searching for ways to do Christianity rather than just simply be a Christian (Cox Hall 2015). Part of its emphasis was a call to move to "abandoned places of empire." Intentional communities began to form across the U.S. mostly in blighted urban areas.

Moving along a separate, but related track, activists began using the term "de-growth" to signify a radical alternative to ways of conceptualizing economic futures. Although de-growth emphasized the reduction of natural resource use, it was also a framework that challenged the widespread notion that growth was good. The movement drew attention to the maladies associated with neoliberalism such as crony capitalism, diminished democracy, inequitable distribution of wealth and resources, as well as decline in overall well-being (Demaria et al. 2013). Embracing earlier critiques of sustainable development by scholars such as Arturo Escobar (1995), who posited that the idea of sustainability was a destructive gloss for growth, de-growth activists sought to politicize and reengage debates about development, critiquing normative economic paradigms while also relying on science to imagine an alternative future (Demaria et al. 2013: 193). Although economics was foundational to the call for de-growth, de-growth became a noneconomic concept that depended on a rethinking of social values and futures (DeMaria et al. 2013: 209). Erik

\footnotetext{
${ }^{2}$ The Fellowship for Intentional Community is an organization founded in 1987. Their website includes classified ads, a retail store, the magazine Communities, and a list of all of member intentional communities. In 2016 there were over 2,500 communities listed in their directory.
} 
Assadourian, a Senior Fellow at the Worldwatch Institute, suggested that expanding the "leadership role of religions could dramatically accelerate the transition to a plenitude society" (2012: 34). Citing various initiatives by leaders of different faiths encouraging its followers to adopt a simpler life, Assadourian hoped that increased leisure, more public space, job-sharing and time spent with one another would compensate for the reduction in consumption.

What might be gained from holding up these two seemingly disparate movements to see how they intersect? Anna Peterson has suggested that environmental ethics are "lived ethics" whose models are often religious (Peterson 2001: 4). Lived ethics not only conceptualize the ways that individuals make choices and pursue futures, but also how ideas and life mutually inform and shape one another (see also Peterson 2009). As Susan Paulson notes in the introduction to this volume (2017), de-growth is everywhere and in different forms. Although not referred to as such, the de-growth movement in many ways promotes a theology of enough. Similarly, residents of many intentional communities promote the values of de-growth. Both the degrowth movement and a theology of enough urge people to fight consumerism, individualism, everincreasing inequality, wasteful resource use, all while promoting relationships, simplicity and quality of life over efficiency, accumulation and incessant work. Even though the majority of the residents I followed in one intentional community may have never heard of de-growth, their experience living some de-growth values sheds light on the pragmatics and possibilities of a plentitude society.

This article begins by asking what does a theology of enough mean and how does it intersect with some of the goals of de-growth? How does life living in intentional community draw on many of the ideas explored in de-growth literature? Furthermore, why has living in community become so attractive to young Christians? Although many intentional communities have adopted some monastic practices such as a daily rule, most participants do not take a vow of poverty, nor are they self-sustaining. How is faith combined with a politics of daily living and how do residents experience living a theology of enough? Drawing on fieldwork conducted with one intentional community in North Carolina over the course of four years, this article suggests that de-growth's call to work less and play more proves to be the most challenging aspect of a life centered on sharing, simplicity and slowing down. Consuming less isn't so difficult. Living together and valuing a life of being, and not doing, is.

\section{A theology of enough}

In the opening sentence from his book section entitled Theology of enough, Shane Claiborne writes: "In addition to rooting simplicity in love, it also seems crucial that economic practices be theologically grounded" (Claiborne 2006: 123). Writing that many of the "terribly disturbing things" that happen in the name of Christ are rooted in bad theology, Christians might follow the Homeless Rabbi instead (Claiborne 2006: 123).

Claiborne's theology of enough has two central claims. First, in contrast to the health and wealth gospel often espoused in mega-churches, poverty or wealth is not something ordained by God but rather created by man. Claiborne cites various scripture passages noting the biblical responsibility Christians have to poor neighbors, for letting land lie fallow, for allowing gleaning, for the redistribution of property, and for the releasing of slaves. Claiborne (2006: 112) argues that when there is too much distance between rich and poor, Christian community becomes impossible. Typical acts of charity are not enough; they can act as "an insulator" rather than a point of connection. Rather than check writing for charity, Jesus wants concrete acts for connection to bring people into relationship (Claiborne 2006: 112).

The second claim of a theology of enough is that to become part of God's Kingdom, Christians must let go of worldly ties - both material and familial - and instead rely on God for life. Claiborne sees this passage as fundamental to entering a "new economy of abundance." "True fasting," he writes, "is not just depriving ourselves of privilege but also sharing sacrificially to bring an end to the cycles of inequality, an end to creation's groaning and the groaning of hungry bellies" (Claiborne 2006: 122). Privilege must be sacrificed. Simplicity is only meaningful if it is "grounded in love, authentic relationships and interdependence." Individual dispossession makes room for the joys of collective possession that happen in the here and now. This is rebirth through economics. The irresistible revolution is "a new and ancient way of life that is so attractive, who would settle for anything else" (Claiborne 2006: 319)? 
Raised as an evangelical Christian in Tennessee, Claiborne is part of a growing group of Christians, mainly in their twenties and thirties, imagining a new world order through the old. ${ }^{3}$ Neo-monastics selectively borrow from traditions such as St. Benedicts Rule, ${ }^{4}$ the Beguines, ${ }^{5}$ or early house churches to create their own tradition. Inspired by figures such as Dorothy Day, Wendell Berry and theologians like Brian McLaren, Alastair MacIntyre, Stanley Hauerwas and Elaine Heath, ${ }^{6}$ neo-monastics believe that this world and its Christianity are broken. Instead, neo-monasticism is counter to individualism "gone wild" and the "violence [that] maintains the privilege to consume" (Stock et al. 2007: 112; see also Wilson-Hartgrove 2009). Rather than worshipping stuff and the idea that what we have is never enough, true Christians might be better worshipping only God and believing in life's abundance that God realizes.

In 2009 Serge Latouche, an economist and Professor Emeritus of the University of Paris-Sud, wrote Farewell to growth (2009). What might be described as a de-growth manifesto, Latouche suggests that in our current state we are headed for an ecological crash. Although we have been aware of the incompatibility of exponential economic growth with environmental welfare since the early 1970s, nothing has been done to elicit wholesale change. The current system, which is based on the continuous need to accumulate, is destructive. Latouche asserts that advertising, easy credit, and planned obsolescence, all participate in the misguided logic of accumulation. The Achilles heel of this logic of accumulation is that it can never slow or stop because panic ensues. Instead, Latouche offers an alternative framework, writing that the goal of degrowth, "is to build a society in which we can live better lives whilst working less and consuming less" (Latouche 2009: 9).

Latouche lays out a three-part plan to realize this "concrete utopia" possible in a "virtuous circle of quiet contraction" (Latouche 2009: 33). ${ }^{7}$ What is first needed is a re-valuation of social values that are connected to a growth paradigm. "Altruism," he writes, "should replace egotism and unbridled competition should give way to cooperation" (2009: 34). Rather than obsessing about work, for example, leisure and play should be valued (2009: 34). Instead of consumerism, without care for the quality of the product or the exploited labor used to produce the good, there might be more emphasis placed on cooperation and craftsmanship. Second, more emphasis on decision-making and production must be made at the local level. Re-localization, the second strategic 'R', proffers that all "economic, political and cultural decisions that can be made at the local level must be made at their level" (2009: 38). Finally, there needs to be a reduction in over-consumption, waste and mass tourism. Overall there must be a "decolonization of the imaginary" (2009: 53).

A theology of enough aligns with many of the ideas of de-growth while simultaneously repositioning those notions through a Christian lens. Like de-growth, a theology of enough offers a post-development, post-growth politics and tackles the economy as much as society. Latouche, for example, suggests that relational goods such as friendship and neighborliness should be encouraged because they are collective goods that do not disappear with sharing (2009: 70). They are, in some sense, the ultimate renewable resource. In his article "De-growth or regrowth?" Mark Whitehead writes that economic activity should focus on enhancing happiness and human well-being, and not the "avaricious pursuit of wealth" (Whitehead 2013: 142). A theology of enough posits that relationships and human connection should be fostered and is foundational to a better world. The justification, however, is not because it is a renewable resource that will help prevent ecological devastation, but because it is Christ's way. While a new way of thinking about home

\footnotetext{
${ }^{3}$ Jonathan Wilson-Hartgrove is also a key figure. A prodigious writer, he went to college with Claiborne and has cowritten several texts with him.

${ }^{4}$ St. Benedicts Rule, written in the late fifth century, was the rule of life for monks living in community under authority of an abbot.

${ }^{5}$ The Beguines were a semi-monastic community of lay leaders in the $13^{\text {th }}$ through $16^{\text {th }}$ century that lived in Northern Europe.

${ }^{6}$ See for example, Heath (2008), Heath and Kisker (2010) and MacIntyre (1981). Heath taught at Southern Methodist University where she started an intentional community program for university students. She has recently started the Missional Wisdom Foundation and was named Dean of Duke Divinity School in 2016.

${ }^{7}$ Latouche draws on Ernst Bloch's distinction between abstract and concrete utopias. As Ruth Levitas (1999) argues, concrete utopias are not simply Marxist in orientation but are any project committed to social transformation.
} 
economies is articulated in a theology of enough (one that is at odds with mass consumerism and the labor that is exploited to produce its goods), the motivation is Christian. A healthier connection to the environment may be a beneficial outcome of a theology of enough, but it isn't the stated goal. ${ }^{8}$

In his book The Economy of desire, theologian Daniel Bell draws on Michel Foucault and Gilles Deleuze to suggest that capitalism is not merely "an economic order but also a discipline of desire" (2012: 38). Capitalism has a specific economic logic wherein all aspects of life have become subsumed into its frame, permeating "into every fiber and cell of human life" (Bell 2012: 76). Bell laments that states no longer regulate the economy but instead serve the economy and that we now must become entrepreneurs of ourselves (2012: 65). Capitalism is devastating precisely because of its "corruption and disordering of desire" that "obstructs communion" (2012: 88). If modern economies are about the labor of human desire, then our desires have become grossly distorted. Instead, capitalism works against the renewal of "communion with God and humanity" (2012: 88). Bell suggests that as consumers we do not desire or relate to one another appropriately. Consumerism, as idol, is false enchantment. Life should be ordered for Jesus not the market (2012: 89). Much like Claiborne, Bell writes that today's economics should align with seemingly self-evident Christian values. Capitalism, he writes, is nothing less than a theological revolution (Bell 2012: 90). Bell wants to reclaim desire for Christianity. Counter to the alienating and destructive aspects of desire expressed in capitalism, desire in Christianity is viewed as therapeutic and restorative. ${ }^{9}$ Desire is a renewable resource. The Divine life of abundance is received through communal practices such as charity and prayer.

Latouche and others espousing de-growth, suggest that the world is comprised of finite resources and that there are limits to the earth's carrying capacity. Too often the earth is viewed as a repository or wastereceptacle for human domination (Latouche 2009: 16). For both Claiborne and Bell the reason why accumulation is critiqued is because it prevents connection with others. That is, rather than be motivated to prevent ecological collapse or to foster democracy, the purpose and foundation for a theology of enough is to usher in the Kingdom where people live in harmony and equilibrium. The welfare of the environment is its happy by-product. Although a theology of enough supports de-growth, more emphasis is placed on social justice, non-hierarchical communitarian values, and general wellbeing as part of the reason for living in community. Of course the levels with which individuals uphold these various social values while living in intentional communities differ not only by the community, but also by individuals living within the same community. Theory and practice diverge and there is often significant variation in the ways Christians interpret beliefs both between and within each community (Droogers and Rostas 1993). Attempting to live a theology of enough while emphasizing community and simplicity is one strategy that aligns with the revaluation goals ongoing in the de-growth movement. In practice, however, attempts to forge this within contemporary U.S. society can be unbearably fractious for those participating in it.

\section{The tension of doing less}

I have followed an upstart intentional community in North Carolina for four years. Now entering its fifth year, the community has seen its fair share of conflict and change. This particular intentional community began as a way to rethink church in a struggling rural Methodist congregation. The church applied for a grant that would provide a small stipend for a group of four, sometimes five, people to occupy the unused parsonage as an intentional community. The hope was that the church might learn something and be invigorated from this group of young people committed to eating together and praying together daily. While the first year was rife with conflict, each year has seen more stability and acceptance of the residents that live behind the congregation's beloved chapel. Over the course of four years, fourteen people have occupied the parsonage. Of that group, five adults and one child lived in the house for two years. The group was comprised mostly of women (all but three) under thirty years old (all but one), who were well educated (all had a college degree), unmarried (all but two couples), and white (all but a couple and their young son who were African-American). Everyone identified as Christian and two were aspiring pastors.

\footnotetext{
${ }^{8}$ Here I am speaking in more general terms, for some eco-Christians this distinction may not be possible.

${ }^{9}$ See Smith and Denton (2005), Dean (2010).
} 
The daily life of this community was organized around prayer and meals. Although this evolved each year to attend to new needs, in general the residents conducted themed prayer in the mornings from Monday to Thursday. Monday morning might focus on lamentation while Thursday might focus on reconciliation. One person led prayer but others voiced their prayer concerns as well. The group also had shared evening prayer, though attendance was often sporadic. There were collective meals two nights a week and a community meal on Wednesday nights where non-residents were invited to dine with the community. The group also had a mid-day prayer. This prayer was performed at-large and acted as a moment for pause, reflection and connection to other members regardless of where the resident found him or herself. The group also led worship on Sunday morning. Friday and Saturday were considered days off.

Because it was aligned with Methodism, their covenant was based on John Wesley's General Rules. The document specified that the community prayed together for themselves and others. According to the covenant, the group should be a presence in their worshipping community and practice radical hospitality. They sought to honor each other's "diverse cultural gifts" ${ }^{10}$ and tried to resist racism and sexism. During the year they committed "to learning to love Jesus better by learning to love each other better." They also wanted to "serve God and neighbor out of gratitude for the love of God." Their pledge to resist consumerism included sharing part of their budget for meals, spending their food budget on local products, and eating simply. They also sought to be a witness, to listen, to learn from the community, to slow down and to live simply.

Many of the residents had read Claiborne's book in college and wanted to live in an intentional community primarily to further their own Christian discipleship. The residents almost always viewed living in community as a challenge to be faithful in the mundane, and to sit together in relationship. The idea of being the truest version of your self was thought to be part of the requirement for living in community, because not inhabiting that self was seen as denying others a relationship with the 'authentic you.' By living with people you trusted, one was able to receive hard truths about self and the world. Thus, residents conceived of the community as the vehicle by which salvation was worked out and a way to live out one's faith and the gospel. In interviews conducted with residents prior to joining the community, they said that they looked forward to a closer walk with Jesus, managing personal conflict, slowing down, accepting living simply, and learning to really say "God is my provider." One resident wanted to live "Kingdom principles rather than seeking pride and hate and hoped to trust in God's grace." Another resident said she looked forward to witnessing God in all arenas, knowing Christ more, articulating the story of Christ, and bringing people into it and ultimately living as a "display of Christ's love no matter where you are."

The decision to live in an intentional community was not taken lightly. Residents had several concerns prior to the decision to move to into the house. Those they shared with me included: finances, not fitting in, living as a family in community, being bored because of slowing down and not working as much, managing other aspects of life such as school, worshipping in a different style and setting, dealing with conflict, not getting along, sliding by and not being intentional, and losing sight of oneself to please people. Still, people wanted to do it because they felt living in community was important. Community provided a sense of place in the world and a feeling that, as one resident framed it, "everything we do matters." For one resident, living in community was biblical. When asked why someone would want to live in community, the resident responded: "I really, really think this is what Jesus wants. It's weird. Living in community has made me stronger as an individual, because you've had to be. Because if you're not self-aware, if you don't have that self-awareness, you just can't be in community. You have to build that." Another felt intentional community was "not required by God, but I just think it's a good way to live out...day to day stuff where your character is just shaped and formed." Living in community had the potential to feed people spiritually because they knew they could be real with one another while still being cared for by the people in the community. Trusting community meant they could be vulnerable with one another and live into themselves.

Over the past four years, the community has seen that intentional living situations can be destructive and harmful, with people feeling isolated and depressed. In this intentional community, even the most mundane action was held up for scrutiny, as all of life became a conversation with Jesus as one's life coach

\footnotetext{
${ }^{10}$ Items in quotations in this section are direct quotes from interviews with residents or from their written covenant.
} 
and spiritual director. The politics of everyday, such as doing dishes or keeping a clean house, became theological conversations in their own right. This often created tension and conflict for the residents. In their interviews all of the residents expressed their frustration and exhaustion with sharing a home. The frustrations of living in community that were most cited by participants I interviewed included: the stress of a shared common space, raising a child communally, yearly transitions between residents, the collapse of boundaries with no space to recharge, not being taken seriously by other adults, and having a long-term vision without a long-term presence. Another frustration shared was that certain aspects of life did not get time or priority.

Rather than view conflict as an impediment to community, however, conflict was universally conceptualized by the residents as the avenue to becoming closer to God and was key to Christian discipleship. As one resident remarked, through conflict residents tried to offer compassion without strings attached and "wait[ed] for God to show up and do something." Another said, theirs is an "unromantic view of Christianity," one that is learning how "to be a community who betrayed Jesus." Another resident appreciated conflict because it forced her to let go, lose control and give power to the Holy Spirit. One resident framed conflict as forcing him to slow down, to consider tension, and not just push an idea through at the expense of community. Conflict was central to the joy the residents experienced because it was through conflict that residents let go of self and relied on God. ${ }^{11}$ Still, the conflict was challenging. At the end of the first year, the project director thought that it was quite significant that nobody had moved out. In that particular year the residents felt frustrated because they didn't know what they were supposed to be doing and felt pressured and critiqued by church members to do more for the community. In year four, a couple did decide to move out because the living situation had become intolerable due to personality conflicts and different ideas about what life in community should look like. At the end of each resident's stay in the community and again a year later I asked residents if they would do it again. Nearly all breathed a deep sigh and paused before responding. Most said yes, but almost always with caveats. Tellingly, several residents said that they would like to live in an intentional Christian community but not one that was residential.

In her work on the role of utopia in intentional communities, Lucy Sargisson suggests that estrangement is necessary to "think the unthinkable and demand the impossible" (2007: 395). People who retreat from the world into intentional communities often experience a type of "permanent social otherness" (Sargisson 2007:417). Such otherness, Sargisson suggests, is necessary because its participants are participating in a process of "deep experimentation with the self [that] requires a safe haven" (Sargisson 2007: 398). Neo-monastics seek to ameliorate some of the permanent social otherness of cloistered communities by not being walled off. Although living as a neo-monastic means selectively choosing practices of the past, such as a rule of life, the purpose of many intentional communities is to be fully situated within the community that surrounds them. Consequently, residents in the community I followed held outside employment or continued their studies. Some worshipped at different churches. They volunteered for civic organizations and at a local elementary school. This insider/outsider integration, however, had its own challenges as pressures from the outside infringed on the ability to build community within. Such exploration of the perfect life can be a life-altering experience and it can also go bad. As Sargisson states about estrangement and utopia: "It is necessary and yet variously unendurable" (Sargisson 2007: 393).

After three years, the community tried to change its model. Viewing the residential group as unsustainable, too grant-dependent and too inward focused, a group comprised of church and community members decided that the intentional community might be better conceptualized as a Community Development Organization. Residents received job titles and a personnel manual was developed. They built a website to take donations. This change partially came from the complaint that some residents had nothing to show on their résumé after living in community. It was not enough to pray and to eat together, one must do something and have something to show for it. What was it they did? How should they spend their time? What impact were they making? Older members of the church often wondered what the residents did and generally had no understanding of the purpose of the community. "Why haven't they cleaned the painting in the sanctuary like I asked?" one congregant asked. "Why haven't they come to church more?" said others.

\footnotetext{
${ }^{11}$ In an interview with Jonathan Wilson-Hartgrove in 2012, he stated that conflict is "where the good stuff happens."
} 
Initially, residents needed to perform a certain amount of tasks to be considered worthy of the project and were eventually considered church staff, as they helped organize music, liturgy and occasionally preached. Just praying and eating together could never be enough and residents often came up with ideas for how they might best spend their time, from starting a second-hand shop, to establishing a co-op, to doing a garden project, to thinking up different worship services. There was constant concern over what to do once the grant ended and how to make the project sustainable.

Thinking about anxiety in de-growth, Erik Assadourian has suggested that contraction "must be tempered with the hope that what is given up will lead to future good" (2012: 26). This, however, does not take into account the very real impact of living with those anxieties. De-growth proponents and neomonastics are not walled off from the world. For example, this particular intentional community is rooted in Methodism. The denomination grew as it came of age in the era of American rugged individualism and the puritan ethos of work (Geyer 1997, see also Weber 1905). Citing scripture in the Book of James, United Methodists in the United States continue to assert that faith and good works go together. Referred to as "practical divinity," United Methodists continually work on putting faith and love into action. ${ }^{12}$ The push from church members, by those formally trained in Methodism and also from the residents themselves to do more or to build membership, meant that a life of prayer and communal living could never be enough. The initial leader of the program felt that without work or service, life in community was simply navel-gazing and was "excruciating." The subsequent leader felt that a strong work ethic was vital. He struggled with trying not to judge other people's idleness and established new programs and outreach projects hoping more people would become active in the community. The residents did have faith in the unseen and not-yet-experienced, but the profound frustration and conflict they experienced in communal living was unbearable and the altered social values often critiqued from all sides.

Taking the monastic precept of collective work, the work of this community is now termed development. They want to build on the assets and resources the larger town might possess and to think of ways to connect people and serve them. Rather than produce a product for their collective needs, as many monastics did and do, this group works at community organizing. Community has become the product. Growth in this sense is good. Even though this community looked for ways to work together to find community based solutions to life's challenges and collectively longed for conviviality, a space for contemplation, and a chance to slow down, doing so has been fractious; perhaps even more work than the life of consumption and accumulation it critiques. If, as Latouche (2009) argues, one aspect of de-growth's revaluation is to dismantle normative ideals about work and one's purpose to include more play, leisure, and relationships, in effect working less, then, based on the experience of the residents in this intentional community, this might be the most difficult task of all. Living together and sharing space with non-kin, even if they eventually become fictive kin, is hard-won. ${ }^{13}$ It seems that moving to an "abandoned space of empire" is something only the privileged can afford.

\section{The political theology of enough}

Sociologists generally view today's growth in intentional communities as tied to the increasing isolation people feel. They posit that there is an increased dissolution of community in modern society and diminishment of social ties and tradition (referred to as gemeinschaft). In response, individuals attempt to reestablish connection and improve their quality of life by forming communities (Smith 2002, see also Putnam 2000). Zygmunt Bauman (2000) also suggests that today's society is characterized by a pervasive unrootedness and looseness of attachment. Such lack of stability in a community, he argues, has significant implications for the ability of people to care about places, people and too affect long-term change. Many

\footnotetext{
12 For more on grace and works, see www.umc.org.

13 One former resident said he felt like a babysitter having to deal with all of the interpersonal conflict. In a personal reflection piece published in Christianity Today, D.L Mayfield writes about the experience of becoming "ClaiborneAgain" (a play on "born-again"). The life of downward mobility was a struggle. Corporate and personal prayer as well as Bible study in community helped sustain the motivation. Citing Jonathan Wilson-Hartgrove, Mayfield writes that those seeking this life might think of it as a repentance movement and a call to be humbled. It isn't the cockroaches or bedbugs that are the issue, but rather the "ordinary pains of struggling with pride and loneliness and greed" (Mayfield 2016).
} 
intentional Christian communities push back against this instability and superficiality by attempting to forge deep ties with a group who share similar values.

Within circles that study Christianity, neo-monasticism is often conceptualized as part of a larger movement referred to as emerging church. Jon Bialecki and James Bielo suggest that earlier modes of Christianity are outmoded and new norms are needed (Bialecki and Bielo 2015; Bielo 2011; see also Miller 1999). Younger Christians are searching for fresh and relevant ways to embody and argue for Christian Truth. Traditional worship simply isn't of interest to them (Bielo 2011). While some argue that the antiinstitutional response of millennial Christians is also a critique of mega-church evangelism and American modernity, others argue that the rejection of institutional forms is part of a historical 500-year cycle (Tickle 2012). Nonetheless, thinking about neo-monasticism and a theology of enough as one of the many global social movements occurring today (such as de-growth, voluntary simplicity, work sharing) offers a different take on neo-monasticism. Neo-monasticism is not simply a religious movement, but a political one, whether those participating in it realize it or not. ${ }^{14}$

Religion in the U.S. has often been oppositional and anti-institutional. In his study of Christian activism at University of Texas, Austin in 1960, Doug Rossinow argues that Christian liberalism and existentialism "played important roles in the emergence of white youth radicalism in the 1960s" (Rossinow 1994: 311, see also Rossinow 1998). Similar to today's Christian millennials, white activist Christians in the 1960s viewed institutional church settings as hypocritical. At the time progressive Christianity allowed for ways to remain faithful while articulating a different understanding about societal norms. A quote from one of the staff members of the YMCA that helped support civil rights in Austin during this period is uncannily similar to Claiborne's call for a theology of enough. "We've tried to show that Christianity isn't just something for Sunday exercise, that Christianity is something that has to do with living seven days a week if it's worth a hoot, that it has something to do with your treatment of people" (quoted in Rossinow 1994: 314). Similar to today's neo-monastics, this Christianity offered guidance for how life should be lived in the here and now.

Neo-monastics or those interested in living in intentional community are often referred to as recovering evangelicals. They enter college with unwavering faith but what they study and learn in college upends much of their previously held beliefs. Neo-monasticism offers evangelicals a way to root their newfound knowledge and current social issues in a reshaped, though still foundational, faith. Consequently, neo-monasticism is an everyday program for utopic living that draws on themes of rootedness and stability ${ }^{15}$, but is also a program to take Christianity seriously as the driver and organizer of one's life. Neo-monasticism folds ethics and social science into a Christian espousal of the quotidian. Heaven is potentially now, and neomonastics are more active in their living of faith, if not self-identified activists.

In Red letter revolution, a book with an accompanying website called 'Red Letter Christians', Shane Claiborne and his mentor Tony Campolo, offer a dialogue on the most pressing social issues of our time from national debts to homosexuality to environmentalism to abortion rights to Islam. ${ }^{16}$ The book asks: "What if Jesus really meant what he said?" Selectively focused on the red lettering used in some Bibles to offset quotations attributed to Jesus, the Gospels become a guidebook for life. ${ }^{17}$ Claiborne suggests in the book that a good litmus test for daily practice might be to ask oneself "Does it look more and more like Jesus (Claiborne and Campolo 2012: 12)?" An evangelical's biblical literalism combined with more leftist politics is articulated with an unwavering conviction for a distinctly $21^{\text {st }}$ century espousal for living. On the back of the book jacket is supportive testimony from Bono, President Jimmy Carter and Archbishop Desmond Tutu.

\footnotetext{
14 Susan Harding (2001) argues that Christian fundamentalism in the 1980s was also political, making history and altering social values.

${ }^{15}$ See Jonathan Wilson-Hartgrove's The wisdom of stability (2010).

${ }^{16}$ Tony Campolo taught Shane Claiborne as well as Jonathan Wilson-Hartgrove when they were students at Eastern University. On his personal website he refers to himself as "The positive prophet of Red Letter Christianity."

17 "The Gospels are a declaration of how to live as kingdom people, working to create the kingdom of God in this world" (Claiborne and Campolo 2012:8). Tanya Luhrmann (2012) also suggests that evangelical Christians read the Bible as a contemporary document that acts as a guide to living life.
} 
In their chapter on environmentalism, Tony Campolo writes that Red Letter Christians are "waking up to the importance of rescuing the environment" (Claiborne and Campolo 2012: 96). Claiborne responds that the environment should be considered the Creator's creation and losing touch with God's creation is thus losing touch with the Creator. The American dream and its "dream of accumulation" are fundamentally at odds with God's dream for humanity (Claiborne and Campolo 2012: 101). Caring for that creation is fundamentally about loving your neighbor, Claiborne writes, as environmental injustices disproportionally affect poorer communities (Claibrone and Campolo 2012: 96).

In both Bell and much of the neo-monastic literature, Christianity is posited as outside of the profane, secular world. Young Christians should move to "abandoned places of empire." Through relocation, they might redistribute and share assets, loving their neighbor. Such physical and ideological estrangement is common in utopic projects (Sargissen 2007). Its abandoned places, however, are singularly imagined and there is a tendency to privilege the pain of only some of them. Nobody is moving into gated communities to be in solidarity with wealthy housewives with prescription drug addiction. ${ }^{18}$ Instead, what is applauded (in the U.S. context) is rooting oneself in the "wrong side of the tracks," in trailer parks, and blighted urban neighborhoods. As a movement mostly comprised of white, middle class and college educated youth, neomonasticism to the outsider can seem like Victorian slumming (Koven 2004). ${ }^{19}$ The authentic way of following Jesus seems to only exist beyond their spaces of privilege. As such the kingdom is attainable only through specific relationships of difference.

Seeking justice and solidarity with the poor and oppressed, while seemingly political activity has also been critiqued for ignoring politics and structural injustices writ large. Tony Campolo asks Claiborne about his reluctance towards politics in Red letter revolution. Claiborne responds that he prefers direct contact and action. Claiborne suggests that we vote everyday, and make choices everyday. Those individualized acts are where ordinary radicals should focus. Rather than simply being Christian, this is doing Christianity in daily practice. This is Christianity with specific faces. Oppression is not tackled structurally but at a micro-level of daily living.

Thus, while neo-monastics attempts to rethink economics out of a capitalocentric frame toward one based on relationships (Gibson-Graham 2004:149), their politics of direct action does not tackle inequalities for those outside of their personal sphere. Neo-monasticism is as much an anti-neoliberal social movement as de-growth, but I am not sure many of its participants would articulate it in this way. Similar to environmental movements in the U.S., a critique of capitalism is not always expressed. Environmentalists, for example, occupy a range of capitalist and non-capitalist discourses, relationships and practices (Shear 2014:206). Unlike other social movements that are often spurred by marginalized groups who are excluded from national narratives of prosperity, ${ }^{20}$ neo-monastics, like those in voluntary simplicity movements, often come from this prosperity. ${ }^{21}$ Consequently, they are not necessarily interested in simply making a living, but rather making a life. They are looking for connection in an increasingly fragmented world. Neo-monasticism, with its emphasis on collective prayer, rules of life and constant reflection about choices through the lens of a specific model of Christianity, permits an everyday politics of living that is oppositional yet on its face does not seem it. No longer evangelical Christians, these are active-ist Christians. This is life as an "ordinary radical."

\section{Conclusion: neo-monastic lessons for de-growth}

Both the de-growth movement and a theology of enough suggest a different logic and desire by which to live. Both critique the idea of status, consumerism, and self over the good of the whole. Both espouse utopic futures in response to the perceived present as dystopia. While some aspects and actors associated

\footnotetext{
${ }^{18}$ See Phyllis Tickle, Emergence Christianity (2012).

${ }^{19}$ This is of course a generalization. In the community I followed, an African-American couple and their young son were residents for two years.

${ }^{20}$ Here I am thinking about indigenous social movements in Canada and South America.

${ }^{21}$ See for example Juliet Schor, Sandy Smith-Nonini, and Josh Lockyer (2017) in this Special Section. See also Shear's description of the environmental movement in Massachusetts (2014).
} 
with de-growth targets and connects the political and economic structure of the larger system in which people live, a theology of enough emphasizes an oppositional politics through personal acts and a reshaping of their relationship with Jesus. The benefit of living in community remains with the individual as they find Jesus' words a roadmap for living. Ordinary radicals are encouraged to pray and perform small acts of kindness and solidarity - eating rice and beans a few times per week or putting money into someone's expired parking meter (see Claiborne et al. 2010). A grander, more collective structural politics isn't necessarily addressed in practice.

Living a theology of enough was not easy. The most significant challenge for those living in the community that I have been accompanying was not making do with less. Sharing meals or pooling resources was comparatively easy. The two biggest challenges for residents were interpersonal conflict and simply accepting the idea of doing less. Pressures to perform, to demonstrate, to show and to do came from outside and well as within the community. For younger and older Christians who grew up in the U.S., this wholesale cultural shift was fraught with peril. How could they possess a Christian love that wanted nothing? How could they be successful? Why weren't more people attending church? What were they doing? The lack of an encompassing structural critique was also part of what made living as an ordinary radical in a neo-monastic community so challenging. Unlike de-growth with its specific aims for reducing resource use, the neomonastics I followed were constantly trying to figure out both what was their purpose and how best to realize it. Not all thought of themselves as activists or even particularly political. They wanted to live a faithful life but what that looked like varied widely amongst the disparate interests of its residents, with American capitalism and consumerism often not being examined. In this sense, the community would have benefitted from de-growth's specificity about its cause and thus its organizing principle.

Many of the ordinary radicals moved by a theology of enough were often those who have benefitted from the very system they were critiquing. Although they felt dissatisfied with the world around them, many were less aware of capitalism's role and a more systemic critique such as the one espoused by many degrowth activists. Ideals of de-growth in this sense were pervasive, even if not consciously so. At the same time, the humanistic goals of sharing, reciprocity, working less and having more leisure proved a utopic vision in practice. The re-valuation of social norms such as sharing space, collectively desiring less doing and being able to value that world may be de-growth's most significant obstacle. Believing that people will share their living quarters, and not want to constantly do, ignores the ways in which many people in the United States have been taught to live for themselves and by themselves. Attempting to change caused real emotional pain and struggle, even if it is what the residents hoped to live by. Based on the residents'

experience, achieving many of the revaluation goals of de-growth required for reducing consumption will necessitate determination, endurance and a singularity of focus to remake a culture of doing into a culture of being. It won't be easy.

\section{References}

Assadourian, E. 2012. The path to de-growth in overdeveloped countries. In State of the World. Washington D.C.: Island Press.

Bauman, Z. 2000. Liquid modernity. Cambridge: Polity Press.

Bell, D. 2012. The economy of desire: Christianity and capitalism in a postmodern world. Grand Rapids, MI: Baker Books.

Bialecki, J. and J. Bielo. 2015. The ancient-future time-crystal: on the temporality of emerging Christianity.

Bielo, J. 2011. Emerging evangelicals: faith, modernity and the desire for authenticity. New York: NYU Press.

Claiborne, S. 2006. The irresistible revolution: living as an ordinary radical. New York: Zondervan Press.

Claiborne, S. and T. Campolo. 2012. Red letter revolution: what if Jesus really meant what he said? Nashville, TN: Thomas Nelson.

Claiborne, S., J. Wilson-Hartgrove and E. Okoro. 2010. Common Prayer: a liturgy for ordinary radicals. Brewster, USA: Paraclete Press. 
Cox Hall, A. 2015. Doing Christianity: intentional communities and social justice in the early 21st century. In J.G. Goulet, L. Murphy and A. Panagakos (eds.) Religious diversity today: experiencing religion in the contemporary world. Westport, USA: Praeger. Academia

Dean, K.C. 2010. Almost Christian: what the faith of our teenagers is telling the American church. Oxford: Oxford University Press.

Demaria, F., F. Schneider, F. Sekulove and J. Martinez-Alier. 2013. What is de-growth? From an activist slogan to a social movement. Environmental Values 22: 191-215.

Droogers, A. and S. Rostas. (eds.). 1993. The popular use of popular religion in Latin America. Amsterdam: CEDLA.

Escobar, A. 1995. Encountering development: the making and unmaking of the third world. Princeton: Princeton University Press.

Geyer, A. F. 1997. Ideology in America: challenges to faith. Louisville: Westminster John Knox Press.

Gibson-Graham, J.K. 2014. Rethinking the economy with thick description and weak theory. Current Anthropology 55(9): 147-153. text

Harding, S. 2001. The book of Jerry Falwell. Princeton: Princeton University Press.

Heath, E. 2008. The mystic way of evangelism: a contemplative vision for Christian outreach. Ada: Baker Academic.

Heath, E. and S.T. Kisker. 2010. Longing for spring: a new vision for Wesleyan community. Eugene: Cascade Books.

Koven, S. 2004. Slumming: sexual and social politics in Victorian London. Princeton: Princeton University Press.

Latouche, S. 2009. Farewell to growth. Malden: Polity Press.

Levitas, R. 1999. Educated hope: Ernst Bloch on abstract and concrete utopia. Utopian Studies 1(2): 13-26.

Lockyer, J. 2017. Community, commons, and degrowth at Dancing Rabbit Ecovillage. Journal of Political Ecology 24: 519-542.

Luhrmann, T.M. 2012. When God talks back: understanding the American evangelical relationship with God. New York: Vintage Books.

MacIntyre, A. 1981. After virtue: a study in moral theory. Notre Dame, USA: University of Notre Dame Press.

Mayfield, D.L. 2016. What it's like to be Shane Claiborne-again. Christianity Today Feb. $19^{\text {th }}$.

Miller, D. 1999. Reinventing American Protestantism: Christianity in the new millenium. Berkeley: UC Press.

Paulson, S. 2017. Degrowth: culture, power and change. Journal of Political Ecology 24: 425-448.

Peterson, A. 2001. Being human: ethics, environment and our place in the world. Berkeley: UC Press.

Peterson, A. 2009. Everyday ethics and social change. New York: Columbia University Press.

Putnam, R. 2000. Bowling alone: the collapse and revival of American community. New York: Simon and Schuster.

Rossinow, D. 1994. "The break-through to new life": Christianity and the emergence of the new left in Austin, Texas, 1956-1964. American Quarterly 46(3): 309-340.

Rossinow, D. 1998. The politics of authenticity: liberalism, Christianity, and the new left in America. New York: Columbia University Press.

Sargisson, L. 2007. Strange places: estrangement, utopianism, and intentional communities. Utopian Studies 18(3): 393-424.

Shear, B. 2014. Making the green economy: politics, desire and economic possibility. Journal of Political Ecology 21: 193-209.

Smith, C. and M.L. Denton. 2005. Soul searching: the religious and spiritual lives of American teenagers. Oxford: Oxford University Press. 
Smith, W. 2002. Intentional communities, 1990-2000: a portrait. Michigan Sociological Review 16 (Fall): 107-131.

Stock, J, T. Otto and J. Wilson-Hartgrove. 2007. Inhabiting the church: biblical wisdom for a new monasticism. Eugene: Cascade Books.

Tickle, P. 2012. Emergence Christianity: what it is, where it is going, and why it matters. Grand Rapids, USA: Baker Books.

Weber, M. 1905/2007. The protestant ethic and the spirit of capitalism. New York: Merchant Books.

Wilson-Hartgrove, J. 2009. God's economy: redefining the wealth and health Gospel. Brewster, USA: Paraclete Press.

Wilson-Hartgrove, J. 2010. The wisdom of stability: rooting faith in a mobile culture. Brewster, USA: Paraclete Press.

Whitehead, M. 2013. Degrowth or regrowth? Environmental Values 22: 141-145. 